\title{
NATURAL RADIOCARBON MEASUREMENTS IN BRAZILIAN SOILS DEVELOPED ON BASIC ROCKS
}

\author{
L. C. R. PESSENDA, ${ }^{1}$ E. P. E. VALENCIA, ${ }^{1}$ P. B. CAMARGO ${ }^{1}$ E. C. C. TELLES, ${ }^{1}$ \\ L. A. MARTINELLI, ${ }^{1}$ C. C. CERRI, ${ }^{1}$ RAMON ARAVENA ${ }^{2}$ and KAZIMIERZ ROZANSKI ${ }^{3}$
}

\begin{abstract}
This paper presents ${ }^{14} \mathrm{C},{ }^{13} \mathrm{C}$ and chemical data of soil organic matter (SOM) in three soil profiles under native forests from Brazil: Londrina (southern), Piracicaba (southeastern) and Altamira (northern). The main objective is to use carbon isotopes in tropical and subtropical soils of Brazil to provide information about vegetation changes that occurred in relation to climate changes during the Holocene. ${ }^{14} \mathrm{C}$ data from SOM indicate that the organic matter in the soils studied is of at least Holocene age. ${ }^{13} \mathrm{C}$ data indicate that $\mathrm{C}_{4}$ plants probably provided the dominant vegetation in Londrina and Piracicaba during the early and mid-Holocene and that $C_{3}$ plants provided the dominant vegetation in the Altamira region during the Holocene.
\end{abstract}

\section{INTRODUCTION}

Radiocarbon dating has been used in soil work since 1950. The main emphasis has been on chronological problems of soil genesis (Martel and Paul 1974), carbon dynamics and identifying parameters for the evaluation of biologically resistant forms of organic matter (O'Brien 1984). Because SOM decomposition and mineralization are relatively slow processes, only a few methods can provide useful data, e.g., long-term experiments or, in some cases, natural ${ }^{13} \mathrm{C}$ measurements (Balesdent 1987).

We report here a list of ${ }^{14} \mathrm{C},{ }^{13} \mathrm{C}$ and chemical data of organic matter from soil profiles in three regions of Brazil. The aim of the project, developed in the Radiocarbon Laboratory of the CENA, was to associate ${ }^{14} \mathrm{C}$ dates with the ${ }^{13} \mathrm{C}$ signature of SOM to study the evolution of local vegetation. ${ }^{14} \mathrm{C}$ data allowed us to estimate $\mathrm{SOM}$ chronology and ${ }^{13} \mathrm{C}$ indicated the vegetation types $\mathrm{C}_{3}$ and $\mathrm{C}_{4}$ of the local paleoenvironment.

\section{STUDY SITES}

L. C. R. Pessenda, E. P. E. Valencia, P. B. Camargo and E. C. C. Telles collected 48 samples from soil profiles under natural forests. In July 1991 , samples were collected from Londrina $\left(51^{\circ} 10^{\prime} \mathrm{W}\right.$ $23^{\circ} 18^{\prime} \mathrm{S}$ ), state of Paraná, southern Brazil and Piracicaba $\left(22^{\circ} 43^{\prime} \mathrm{S} 47^{\circ} 38^{\prime} \mathrm{W}\right)$, São Paulo, southeastern Brazil. The site of Altamira (52 $\left.58^{\prime} \mathrm{W}, 3^{\circ} 30^{\prime} \mathrm{S}\right)$, Pará, northern Brazil, was sampled in February 1992. The natural forest at Londrina and Piracicaba is a Mesophitic semideciduous type and Altamira is part of the Amazon forest (Fig. 1).

The soils of Londrina and Altamira are clayey, with kaolinite predominating, and are classed as "Terra Roxa Estruturada", according to the Brazilian soil classification, "Alfisol" in Soil Taxonomy (USDA) and "Nitosol" in the FAO soil classification system. The clayey and kaolinitic soil at Piracicaba is called "Latossolo Vermelho Escuro" (Dark Red Latosol), according to Brazilian soil classification, "Oxisol" in Soil Taxonomy; "Ferralsol" in FAO classification.

\footnotetext{
${ }^{1}$ Centro de Energia Nuclear na Agricultura, Universidade de São Paulo, 13400-970 Piracicaba, Săo Paulo, Brazil

${ }^{2}$ Earth Science Department, University of Waterloo, Waterloo, Ontario, Canada N2L 3G1

${ }^{3}$ Isotope Hydrology Section, International Atomic Energy Agency, Wagramerstr. 5, P. O. Box 100, A-1400 Vienna, Austria
} 


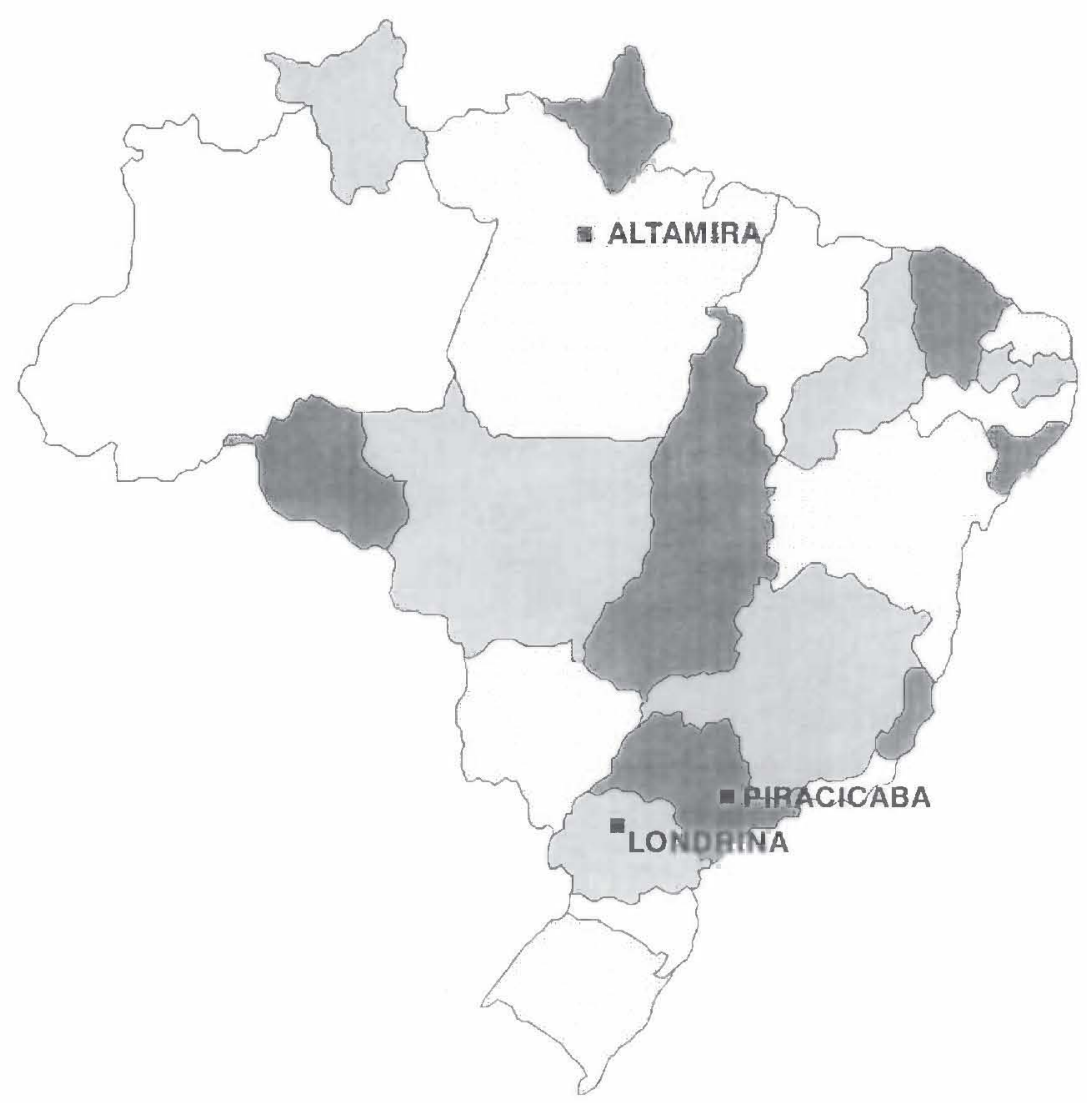

Fig. 1. Map of Brazil showing study sites

\section{METHODS}

At all sites, soils were sampled by collecting up to $5 \mathrm{~kg}$ in $10-\mathrm{cm}$ increments from the surface to 180 $\mathrm{cm}$ depth. Samples for total SOM analyses $(1 \mathrm{~kg})$ were dried at $60^{\circ} \mathrm{C}$ to constant weight and root fragments were discarded by handpicking. Any remaining plant debris was removed by flotation in $\mathrm{HCl} 0.01 \mathrm{M}$ and redried to constant weight. In order to minimize the effects of sample heterogeneity, all samples were ground, sieved $(<200 \mu \mathrm{m})$ and homogenized for ${ }^{13} \mathrm{C}$ and ${ }^{14} \mathrm{C}$ measurements. The humin fraction was extracted from the $200 \mu \mathrm{m}$ fraction $(2.5 \mathrm{~kg}$ ) according to conventional methods (Dabin 1971; Goh 1978; Anderson and Paul 1984): 1) acid digestion in hydrochloric acid $0.5 \mathrm{M}$ at $70^{\circ} \mathrm{C}-80^{\circ} \mathrm{C}$ for $4 \mathrm{~h}$ and washing with distilled water until $\mathrm{pH}$ reaches $3-4 ; 2$ ) reaction of solid residue with at least 30 liters (10 liters per extraction) of sodium pyrophosphate-sodium hydroxide 0.10 $\mathrm{M}$ for $\mathrm{ca} .36 \mathrm{~h}$ (12 h per extraction) and washing with distilled water until the $\mathrm{pH}$ reaches $3-4 ; 3$ ) hydrolysis of solid residue with 4 liters of $3 \mathrm{M} \mathrm{HCl}$ at $100^{\circ} \mathrm{C}$ for $12 \mathrm{~h}$, washing until the $\mathrm{pH}$ reaches $3-4$; and 4) the solid residue was dried at $40^{\circ} \mathrm{C}$ for $48 \mathrm{~h}$ and sieved $(<200 \mu \mathrm{m})$.

${ }^{14} \mathrm{C}$ dating, $\delta^{13} \mathrm{C}$ and chemical analyses were performed between August 1991 and November 1992. ${ }^{14} \mathrm{C}$ analyses were carried out on total SOM and the humin fraction using benzene and liquid scintillation counting (Pessenda and Camargo 1991). Benzene samples were counted for at least $48 \mathrm{~h}$ in a low-level Packard 1550 liquid scintillation spectrometer. ${ }^{14} \mathrm{C}$ ages are expressed in conventional 
years BP and percent modern carbon (pMC) relative to $95 \%$ of the activity of the NIST oxalic acid standard (HOxI) and normalized to a $\delta^{13} \mathrm{C}$ of $-25 \%$ PDB (Stuiver and Polach 1977). The analytical precision is $\pm 1.0 \mathrm{pMC}$.

The stable carbon isotopic ratios $\left({ }^{13} \mathrm{C} /{ }^{12} \mathrm{C}\right)$ of SOM were determined by isotope ratio mass spectrometry using $\mathrm{CO}_{2}$ from samples combusted at $900^{\circ} \mathrm{C}$ in an atmosphere of pure oxygen. Results are expressed as $\delta^{13} \mathrm{C}$ with respect to PDB standard in the conventional (\%o) notation; the analytical precision is $\pm 0.2 \%$. Carbon contents of soil samples were determined, using $1-5 \mathrm{~g}$ of the $<200 \mu \mathrm{m}$ sized fraction, using a C,H autoanalyzer. All samples were analyzed 2 or 3 times, with a coefficient of variation $<4 \%$; values are expressed as weight percent of dry sample. Nitrogen contents were determined using $0.7 \mathrm{~g}$ of $<200 \mu \mathrm{m}$ fraction using the Kjeldahl method; values are expressed as weight percent of dry sample. Soil density was calculated by collecting a mass of soil in a small cylinder of known volume. After drying to constant mass, the density was calculated. The soil $\mathrm{pH}$ was determined in water.

\section{RESULTS AND DISCUSSION}

Tables 1 through 3 show ${ }^{14} \mathrm{C}, \delta^{13} \mathrm{C}$, total organic carbon, total nitrogen, soil bulk density and soil $\mathrm{pH}$ values obtained for total SOM from Londrina, Piracicaba and Altamira, respectively. All the soil profiles show decreasing ${ }^{14} \mathrm{C}$ content with depth, except for the $140-150 \mathrm{~cm}$ sample interval of Altamira profile, which seems to record an age reversal. All surface samples have ${ }^{14} \mathrm{C}>100 \mathrm{pMC}$, showing the influence of thermonuclear ${ }^{14} \mathrm{C}$ in the recent organic matter. $\delta^{13} \mathrm{C}$ values between the surface and the $40-50 \mathrm{~cm}$ interval are indicative of $C_{3}$ plants, and this reflects the current local vegetation (forest) in all three regions. These values remained almost constant for the Altamira profile from the soil surface to $180 \mathrm{~cm}$ depth; however, the Londrina and Piracicaba soils show a significant change from $-21.6 \%$ to $-15 \%$ in ${ }^{13} \mathrm{C}$ values.

TABLE 1. Londrina Soil Profile

\begin{tabular}{|c|c|c|c|c|c|c|c|c|c|}
\hline $\begin{array}{l}\text { Lab code } \\
\text { (CENA-) }\end{array}$ & $\begin{array}{c}\text { Sample } \\
\text { horizon } \\
(\mathrm{cm})\end{array}$ & $\begin{array}{c}{ }^{14} \mathrm{C} \\
(\mathrm{pMC})\end{array}$ & $\begin{array}{c}{ }^{14} \mathrm{C} \\
\text { (yr BP) }\end{array}$ & $\begin{array}{l}\delta^{13} \mathrm{C} \\
(\% 0)\end{array}$ & $\begin{array}{l}\text { Total C } \\
\text { (wt \%) }\end{array}$ & $\begin{array}{c}\text { Total } \\
\mathrm{N} \\
\text { (wt \%) }\end{array}$ & $\mathrm{C} / \mathrm{N}$ & $\begin{array}{c}\text { Soil } \\
\text { bulk } \\
\text { density } \\
(\mathrm{g} / \mathrm{cc})\end{array}$ & $\begin{array}{l}\text { Soil } \\
\mathrm{pH}\end{array}$ \\
\hline 194 & 0 to 10 & $110 \pm 1.2$ & -- & -25.8 & 1.85 & 0.21 & 8.81 & $1.23^{*}$ & $5.4^{*}$ \\
\hline -- & 10 to 20 & -- & -- & -25.1 & 1.43 & 0.16 & 8.94 & -- & -- \\
\hline -- & 20 to 30 & -- & -- & -24.3 & 1.59 & 0.19 & 8.42 & $1.23^{*}$ & $5.3^{*}$ \\
\hline-- & 30 to 40 & -- & -- & -24.2 & 1.29 & 0.15 & 8.60 & -- & -- \\
\hline 193 & 40 to 50 & $90.3 \pm 0.7$ & $820 \pm 60$ & -23.8 & 1.02 & 0.13 & 7.85 & -- & -- \\
\hline-- & 50 to 60 & -- & -- & -23.2 & 1.00 & 0.11 & 9.09 & -- & -- \\
\hline-- & 60 to 70 & -- & -- & -22.2 & 0.89 & 0.10 & 8.90 & $1.25^{*}$ & $5.5^{*}$ \\
\hline 192 & 70 to 80 & $78.8 \pm 1.1$ & $1920 \pm 60$ & -21.6 & 0.86 & 0.09 & 9.56 & -- & -- \\
\hline-- & 80 to 90 & -- & -- & -21.0 & 0.85 & 0.09 & 9.44 & -- & -- \\
\hline 196 & 90 to 100 & $74.3 \pm 0.8$ & $2390 \pm 60$ & -21.3 & 0.99 & 0.10 & 10.00 & -- & -- \\
\hline -- & 100 to 110 & -- & - & -19.4 & 0.82 & 0.08 & 10.25 & -- & -- \\
\hline.- & 110 to 120 & -- & -- & -18.5 & 0.71 & 0.07 & 10.00 & -- & -- \\
\hline 195 & 120 to 130 & $50.8 \pm 0.7$ & $5450 \pm 90$ & -16.8 & 0.71 & 0.06 & 11.83 & -- & -- \\
\hline -. & 130 to 140 & -- & -- & -16.7 & 0.73 & 0.06 & 12.17 & -- & -- \\
\hline-- & 140 to 150 & -- & -. & -15.5 & 0.78 & 0.06 & 13.00 & $1.43^{*}$ & $5.3^{*}$ \\
\hline-- & 150 to 160 & -- & -- & -15.1 & 0.88 & 0.05 & 17.80 & -- & -- \\
\hline-- & 160 to 170 & -- & -- & -14.9 & 0.87 & 0.05 & 17.40 & -- & -- \\
\hline 218 & 170 to 180 & $31.3 \pm 0.5$ & $9340 \pm 120$ & -15.0 & 0.93 & 0.05 & 18.60 & -- & -- \\
\hline
\end{tabular}

*Values obtained from Ref. 8 
TABLE 2. Piracicaba Soil Profile

\begin{tabular}{cccccccccc}
\hline $\begin{array}{c}\text { Lab code } \\
\text { (CENA-) }\end{array}$ & $\begin{array}{c}\text { Sample } \\
\text { horizon } \\
\text { (cm) }\end{array}$ & $\begin{array}{c}{ }^{14} \mathrm{C} \\
\text { (pMC) }\end{array}$ & $\begin{array}{c}{ }^{14} \mathrm{C} \\
\text { (yr BP) }\end{array}$ & $\begin{array}{c}\delta^{13} \mathrm{C} \\
(\% 0)\end{array}$ & $\begin{array}{c}\text { Total C } \\
\text { (wt \%) }\end{array}$ & $\begin{array}{c}\text { Total N } \\
\text { (wt \%) }\end{array}$ & $\begin{array}{c}\text { C/N } \\
\text { (w/cc) }\end{array}$ & $\begin{array}{c}\text { Soil bulk } \\
\text { density } \\
\text { (wH }\end{array}$ \\
\hline 184 & 0 to 10 & $107.3 \pm 0.8$ & -- & -25.7 & 2.67 & 0.30 & 8.90 & $1.22^{*}$ & $5.8^{*}$ \\
-- & 10 to 20 & -- & -- & -25.7 & 1.59 & 0.16 & 9.94 & $1.35^{*}$ & $5.0^{*}$ \\
-- & 20 to 30 & -- & -- & -25.6 & 1.12 & 0.11 & 10.18 & $1.21^{*}$ & $5.0^{*}$ \\
-- & 30 to 40 & -- & -- & -23.8 & 0.96 & 0.09 & 10.67 & $1.16^{*}$ & $5.0^{*}$ \\
191 & 40 to 50 & $85.8 \pm 0.9$ & $1230 \pm 90$ & -22.7 & 0.79 & 0.07 & 11.29 & $1.29^{*}$ & $4.7^{*}$ \\
-- & 50 to 60 & -- & -- & -21.6 & 0.63 & 0.06 & 10.50 & -- & $5.0^{*}$ \\
-- & 60 to 70 & -- & -- & -19.7 & 0.63 & 0.05 & 12.60 & -- & $5.2^{*}$ \\
223 & 70 to 80 & $71.8 \pm 0.7$ & $2680 \pm 70$ & -19.0 & 0.64 & 0.05 & 12.80 & -- & $5.2^{*}$ \\
-- & 80 to 90 & -- & -- & -18.7 & 0.63 & 0.05 & 12.60 & -- & -- \\
222 & 90 to 100 & $68.8 \pm 0.7$ & $3030 \pm 70$ & -17.2 & 0.56 & 0.04 & 14.00 & -- & -- \\
-- & 100 to 110 & -- & -- & -16.8 & 0.56 & 0.04 & 14.00 & -- & -- \\
221 & 110 to 120 & $66.8 \pm 0.7$ & $3260 \pm 70$ & -17.5 & 0.54 & 0.04 & 13.50 & -- & -- \\
-- & 120 to 130 & -- & -- & -16.8 & 0.47 & 0.04 & 11.75 & -- & -- \\
-- & 130 to 140 & -- & -- & -16.7 & 0.43 & 0.04 & 10.75 & -- & -- \\
220 & 140 to 150 & $63.8 \pm 0.6$ & $3640 \pm 70$ & -16.7 & 0.43 & 0.04 & 10.75 & -- & $5.3^{*}$ \\
\hline
\end{tabular}

*Values obtained from Ref. 9

TABLE 3. Altamira Soil Profile

\begin{tabular}{|c|c|c|c|c|c|c|c|c|c|}
\hline $\begin{array}{l}\text { Lab code } \\
\text { (CENA-) }\end{array}$ & $\begin{array}{c}\text { Sample } \\
\text { horizon } \\
(\mathrm{cm})\end{array}$ & $\begin{array}{c}{ }^{14} \mathrm{C} \\
(\mathrm{pMC})\end{array}$ & $\begin{array}{c}{ }^{14} \mathrm{C} \\
\text { (yr BP) }\end{array}$ & $\begin{array}{l}\delta^{13} \mathrm{C} \\
(\%))\end{array}$ & $\begin{array}{l}\text { Total C } \\
\text { (wt \%) }\end{array}$ & $\begin{array}{l}\text { Total N } \\
\text { (wt \%) }\end{array}$ & $\mathrm{C} / \mathrm{N}$ & $\begin{array}{c}\text { Soil bulk } \\
\text { density } \\
\text { (g/cc) }\end{array}$ & $\begin{array}{l}\text { Soil } \\
\mathrm{pH}\end{array}$ \\
\hline 239 & 0 to 10 & $103.9 \pm 0.8$ & - & -26.7 & 1.40 & 0.18 & 7.78 & $1.39 *$ & $5.5^{*}$ \\
\hline-- & 10 to 20 & -- & -- & -25.6 & 0.78 & 0.12 & 6.50 & -- & - \\
\hline-- & 20 to 30 & -- & -- & -26.8 & 0.81 & 0.10 & 8.10 & $1.43^{*}$ & $5.1^{*}$ \\
\hline-- & 30 to 40 & -- & - & -25.7 & 0.68 & 0.09 & 7.55 & -- & -- \\
\hline 237 & 40 to 50 & $84.1 \pm 0.7$ & $1440 \pm 70$ & -25.7 & 0.57 & 0.08 & 7.12 & -- & -- \\
\hline-- & 50 to 60 & -- & -- & -25.8 & 0.53 & 0.07 & 7.57 & -- & -- \\
\hline-- & 60 to 70 & -- & -- & -25.6 & 0.41 & 0.07 & 5.86 & -- & -- \\
\hline 236 & 70 to 80 & $70.8 \pm 0.7$ & $2790 \pm 80$ & -25.4 & 0.39 & 0.06 & 6.50 & -- & -- \\
\hline-- & 80 to 90 & -- & -- & -26.8 & 0.26 & 0.06 & 4.33 & -- & -- \\
\hline 233 & 90 to 100 & $63.5 \pm 0.7$ & $3640 \pm 90$ & -25.6 & 0.28 & 0.05 & 5.60 & -- & -- \\
\hline-- & 100 to 110 & -- & -- & -25.7 & 0.23 & 0.05 & 4.60 & -- & -- \\
\hline 232 & 110 to 120 & $55.0 \pm 0.6$ & $4800 \pm 80$ & -25.0 & 0.25 & 0.04 & 6.25 & -- & -- \\
\hline-- & 120 to 130 & -- & - & -25.3 & 0.22 & 0.04 & 5.50 & -- & -- \\
\hline-- & 130 to 140 & -- & -- & -25.5 & 0.25 & 0.04 & 6.25 & -- & -- \\
\hline 231 & 140 to 150 & $57.9 \pm 0.6$ & $4390 \pm 90$ & -26.5 & 0.31 & 0.04 & 7.75 & $1.41^{*}$ & $5.9 *$ \\
\hline
\end{tabular}

*Values obtained from Ref. 8

Taking into account the increase of ${ }^{14} \mathrm{C}$ age with depth, the increase of $\delta^{13} \mathrm{C}$ can be explained in two ways: 1) organic matter decomposition leads to the accumulation and transport of ${ }^{13} \mathrm{C}$-enriched materials with depth in the profile; 2) during the pedological evolution of the soil profiles, the dominant vegetation changed from $\mathrm{C}_{4}$ - to $\mathrm{C}_{3}$-dominant photosynthetic pathway. Similar ${ }^{13} \mathrm{C}$ records have also been documented in other studies in Brazil (Cerri 1986; Rocha 1990; Desjardins et al. 1991). Research is underway to test the postulated hypotheses, e.g., phenol lignin analysis of selected soil samples to characterize past vegetation change in south and southeast regions of Brazil. Paleoenvironmental changes during the last $30 \mathrm{ka} \mathrm{yr} \mathrm{BP}$ have been documented in Central Brazil and the Amazon basin (Absy et al. 1991; Ledru 1993). Based on pollen analyses, these studies indicate periods of forest regression changing to savanna-type vegetation. Such evidence supports vegetation 
changes as an explanation for the ${ }^{13} \mathrm{C}$ trend observed in the Piracicaba and Londrina soils. Work in progress in soils from Central Brazil will contribute to the understanding of the carbon isotopic record in Brazilian soils.

Table 4 shows ${ }^{14} \mathrm{C}$ dates, $\delta^{13} \mathrm{C}$ and total carbon of the humin fraction from the same sites. In general, these data show less ${ }^{14} \mathrm{C}$ content for the humin fraction compared to bulk SOM. This difference is most pronounced in the Altamira soil. Similar patterns have been reported in other studies (Martel and Paul 1974; Campbell et al. 1967; Nowaczyk and Pazdur 1990). This reflects that SOM is composed of fractions of different age. Humic and fulvic acids that are removed during humin extraction are more mobile and can be sources of younger carbon transported downward from the shallow part of the soil. In the case of ${ }^{13} \mathrm{C}$, we observed no significant differences between SOM and humin samples. The total carbon concentration of the humin fraction is significantly (up to five times) less than that of SOM. The results and ideas presented in the paper will be discussed in detail elsewhere, as a component of more comprehensive publications (Martinelli et al. 1996; Pessenda et al. in press).

TABLE 4. Humin Fraction of Soils of Londrina, Piracicaba and Altamira

\begin{tabular}{clccccc}
\hline $\begin{array}{c}\text { Lab code } \\
\text { (CENA-) }\end{array}$ & Site & $\begin{array}{c}\text { Sample } \\
\text { horizon }(\mathrm{cm})\end{array}$ & $\begin{array}{c}{ }^{14} \mathrm{C}(\mathrm{pMC}) \\
\text { humin }\end{array}$ & $\begin{array}{c}{ }^{14} \mathrm{C}(\mathrm{pMC}) \\
\text { total SOM }\end{array}$ & $\begin{array}{c}\delta^{13} \mathrm{C} \\
(\%) \\
\text { humin }\end{array}$ & $\begin{array}{c}\text { Total C } \\
\text { (wt \%) } \\
\text { humin }\end{array}$ \\
\hline 241 & Londrina & 40 to 50 & $72.9 \pm 0.7$ & $90.3 \pm 0.7$ & -22.9 & 0.22 \\
230 & Londrina & 90 to 100 & $68.1 \pm 0.6$ & $74.3 \pm 0.8$ & -21.3 & 0.24 \\
240 & Londrina & 170 to 180 & $26.1 \pm 0.4$ & $31.3 \pm 0.5$ & -14.5 & 0.25 \\
243 & Piracicaba & 70 to 80 & $65.1 \pm 0.9$ & $71.8 \pm 0.7$ & -19.3 & 0.13 \\
242 & Piracicaba & 90 to 100 & $59.1 \pm 0.8$ & $68.8 \pm 0.7$ & $*$ & $*$ \\
246 & Piracicaba & 110 to 120 & $57.8 \pm 0.9$ & $66.8 \pm 0.7$ & -17.4 & 0.11 \\
249 & Altamira & 50 to 60 & $56.6 \pm 0.6$ & -- & -26.4 & 0.12 \\
250 & Altamira & 100 to 110 & $36.5 \pm 0.5$ & -- & -25.8 & 0.13 \\
248 & Altamira & 130 to 140 & $29.5 \pm 0.5$ & -- & -26.2 & 0.10 \\
\hline
\end{tabular}

${ }^{*}$ Insufficient material

\section{ACKNOWLEDGMENTS}

This research was sponsored by the São Paulo Foundation for Research (FAPESP), Grant 90/33120, International Atomic Energy Agency (IAEA) Project BRA/0/010 and the National Council for Scientific and Technological Development (CNPq) Grant 500486/90-5. We thank Álvaro A. T. Vargas and Susan Trumbore for linguistic improvement, Geraldo Cesar Rocha for support in collecting soil samples from Londrina and Altamira, and Maria Valéria Lopes Cruz and Paulo Ferreira for carrying out the benzene synthesis of total SOM and humin samples.

\section{REFERENCES}

Absy, M. L., Cleef, A., Fournier, M., Martin, L., Servant, M., Sifeddine, A., Ferreira da Silva, M., Soubies, F., Suguio, K., Turcq, B. and van der Hammen, T. 1991 Mise en évidence de quatre phases d'ouverture de la forêt dense dans le sud-est de l'Amazonie au cours des 60000 dernières années. Première comparaison avec d'autres régions tropicales. Comptes Rendus de l'Académie des Sciences de Paris. 2nd series, 312: 673-678.

Anderson, D. W. and Paul, E. A. 1984 Organo-mineral complexes and their study by radiocarbon dating.Jour- nal of the American Soil Science Society 48: 298-301. Balesdent, J. 1987 The turnover of soil organic fractions estimated by radiocarbon dating. The Science of the Total Environment 62: 405-408.

Campbell, C. A., Paul, E. A., Rennie, D. A. and MacCallum, K. J. 1967 Applicability of the carbon dating method of analysis to soil humus studies. Soil Science 104(3): 217-224.

Cerri, C. C. (ms.) 1986 Dinâmica da matéria orgânica do solo no agrossistema cana-de-açucar. Livre Docencia 
thesis, University of São Paulo.

Dabin, B. 1971 Etude d'une méthode d'extraction de la matière humique du sol. Science du Sol 1: 47-63.

Desjardins, T., Volkoff, B., Andreux, F. and Cerri, C. 1991 Distribution du carbone total et de l'isotope ${ }^{13} \mathrm{C}$ dans le sols ferrallitiques du Brésil. Science du Sol 29: 175-187.

Goh, K. M. and Molloy, B. P. J. 1978 Radiocarbon dating of paleosols using organic matter components. The Journal of Soil Science 29(4): 567-573.

Ledru, M. P. 1993 Late Quaternary environmental and climatic changes in Central Brazil. Quaternary Research 39: 90-98.

Martel, Y. A. and Paul, E. A. 1974 The use of radiocarbon dating of organic matter in the study of soil genesis. Soil Science Society of America Proceedings 38: 501-506.

Martinelli, L. A., Pessenda, L. C. R., Valencia, E. P. E., Camargo, P. B., Telles, E. C. C., Cerri, C. C., Victória, R. L., Aravena, R., Richey, J. E. and Trumbore, S. 1996 Carbon-13 variation with depth in soils of Brazil and climate change during the Quaternary. Oecologia 106: 376-381.
Nowaczyk, B. and Pazdur, M. F. 1990 Problems concerning the ${ }^{14} \mathrm{C}$ dating of fossil dune soils. Quaestiones Geographicae 11/12: 135-151.

O'Brien, B. J. 1984 Soil organic fluxes and turnover rates estimated from radiocarbon enrichment. Soil Biology and Biochemistry 16: 115-120.

Pessenda, L. C. R and de Camargo, P. B. 1991 A new radiocarbon dating laboratory in Brazil (abstract). $R a$ diocarbon 33(2): 230.

Pessenda, L. C. R., Valencia, E. P. E., Aravena, R., Telles, E. C. C. and Boulet, R., in press, Paleoclimate studies in Brazil using carbon isotopes in soils. In Wasserman, J. C. F. A., ed., Environmental Geochemistry of Tropical Countries. Niterói, Rio de Janeiro, Federal Fluminense University Press.

Rocha, G. C. (ms.) 1990 Características da Dinâmica de Coberturas Pedológicas Sobre Rochas Básicas nas Regiōes Norte e Sul do Brasil. Ph.D. dissertation, University of São Paulo, Brazil.

Stuiver, M. and Polach, H. A. 1977 Discussion: Reporting of ${ }^{14} \mathrm{C}$ data. Radiocarbon 19(3): 355-363. 